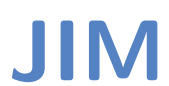

ISSN: 2183-0606

(CC BY 3.0)

Vol. $9,1(2021)$

p. $51-69$

AM: Feb2021

SM: Jul2020

\title{
Innovation Cognizance and Acceptance: The Case of Electric Vehicle Adoption in Ontario, Canada
}

\author{
Ranjita M. Singh ${ }^{1}$, Philip R. Walsh ${ }^{2}$, and Joshua I. Goodfield ${ }^{3}$ \\ ${ }^{1}$ Ted Rogers School of Management, Ryerson University. 350 Victoria St, Toronto, ON M5B 2K3 | \\ ranjita.singh@ryerson.ca \\ ${ }^{2}$ Ted Rogers School of Management, Ryerson University, Toronto, Ontario, Canada | prwalsh@ryerson.ca \\ ${ }^{3}$ Environmental Applied Science and Management, Ryerson University Toronto, Ontario, Canada | \\ joshua.goodfield@ryerson.ca
}

\begin{abstract}
This study examines the results of a survey of 1,000 Canadian internal combustion engine (ICE) vehicle owners to assess factors that would encourage them to purchase an electric vehicle (EV). Further to the work of Peters and Dutschke (2014) and (Matthews et al. (2017) we combine the various drivers of EV adoption, independently identified in the literature, into one model in order to investigate their influence on the intent to purchase an EV. Through correlations and a series of probit regression modelling, we provide evidence to support additional policies that could establish greater relative advantages for owning an EV. These include the promotion of the communication of those advantages through experiential awareness initiatives such as improved access to EV test drives and consumer information. We suggest that car dealerships are important partners in this journey and their association is critical for greater diffusion of EVs in the market. Our findings have implications for EV manufacturers and government policy makers.
\end{abstract}

Keywords: Electric Vehicles; Technology diffusion; Innovation Adoption; Sustainable Transportation; Ontario, Canada.

Cite paper as: Singh, R.M., Walsh, P.R., Goodfield, J.I., (2021). Innovation Cognizance and Acceptance: The Case of Electric Vehicle Adoption in Ontario, Canada, Journal of Innovation Management, 9(1), 51-69.; DOI: https://doi.org/10.24840/2183-0606_009.001_0005

\section{Introduction}

The current energy and environmental policy of the Federal government in Canada has attempted to stimulate consumer interest in purchasing electric vehicles (EV) as a solution to reducing greenhouse gas (GHG) emissions in Canada ${ }^{1}$. In 2017, the transportation sector in Canada accounted for $24 \%$ of GHG emissions ( 174 megatonnes of carbon dioxide equivalent) making it the second largest contributor next to the oil and gas industry, and from 1990 to 2017, emissions from transportation has grown by $43 \%{ }^{2}$

The dense urban environment of the Greater Toronto and Hamilton urban area (GTHA) underscores transportation-related challenges such as traffic congestion and local pollution (Koropeski et al. 1988; Levinson, 1998; McKitrick, 2006; Nagorsky et al, 2016). Even though there were more electric vehicles (EVs) sold in Canada in one year (2018) than the total of the previous three years this increased uptake was only about $2 \%$ of the total sales of vehicles (Klippenstein, 2019). The

1. https://toronto.citynews.ca/2019/05/01/federal-rebates-electric-car/ - Accessed May 24, 2020

2. https://www.canada.ca/content/dam/eccc/documents/pdf/cesindicators/ghg-emissions/2019/ national-GHG-emissions-en.pdf - Accessed May 26, 2020 
transportation sector is recognized as a major contributor of GHG emissions but even mandating legislation that requires automakers to invest in clean technology and provide EVs can only be successful when there is widespread adoption of the same by consumers (Kang and Holbrook, 2015). We seek to investigate unidentified barriers at the market level of a new technology that may be hindering mass uptake of these vehicles amongst a mainstream population by studying the internal combustion engine (ICE) user's likelihood of purchasing an EV.

From a public policy standpoint, 96 supply and demand-driven policies in Canada that support EV uptake have been identified (Melton et al, 2017). Three provinces (British Columbia, Ontario, Quèbec) with government-led incentive programs represented over $95 \%$ of national EV sales. Almost $95 \%$ of BC's and $99.8 \%$ of Quebec's electricity comes from renewable sources such as hydro, wind and solar, making a compelling case for promoting EVs there as EVs can be charged using clean energy thereby increasing their impact on GHG emissions reduction. In 2018, the combination of renewable sources and non-carbon emitting nuclear power generated $93 \%$ of Ontario's electricity and, with a much larger population as compared to either BC or Quebec, making EVs more attractive in Ontario would increase their uptake nationally. ${ }^{3}$

Policy decisions for emerging technologies such as the EV drastically affect its market performance (Webb et al., 2017). We suggest that a better understanding of the key drivers for EV adoption within the context of Ontario might assist in positively informing future policy that could encourage consumers to choose an EV over an ICE vehicle. Ontario is home to almost $40 \%$ of the Canadian population and Ontario's capital, Toronto is the most populous and diverse city in Canada. While various factors related to EV adoption have been separately identified in the literature, their relative importance is unclear. Including them in one model can provide additional insight for appropriate policy development to encourage EV adoption both locally and nationally.

Our paper has a number of sections. We start with a literature review of EV adoption research. From the literature, we derive a model for examining specific drivers of EV adoption and their influence on consumer intent to purchase an EV. We used the model to create our survey design as detailed in the methodology section and this is followed by analysis and discussion of the results from the survey administered to 1,000 ICE drivers in the GTHA. Finally, we conclude with a summary of the results and their implications for future adoption of EVs.

\section{Literature review on EV Adoption}

The GTHA is the largest urban corridor in the Province of Ontario, and akin to many urban areas, faces a number of challenges pertaining to GHG emissions reduction, air quality, and urban sprawl. Increasing environmental consciousness has focussed attention on urban reform and emissions reductions goals have been set up at the National, provincial and city levels. As a result of this recent prioritization, the electrification of transportation is considered an important route to reduced GHG emissions. But consumer acceptance of EVs is essential for their successful diffusion in the market. Studies in the North American context find pervasive dissatisfaction with the initial purchase price of EVs among prospective buyers and concerns regarding the EVs range and perceived charging facilities (Axsen and Kurani, 2012; Krause et al, 2013; Krause et al, 2016; Liu and Cirillo, 2018) including widespread misinformation and misunderstandings about an EV (technology, performance, market availability, infrastructure). While governments have provided financial incentives to buy EVs, there remains controversy over the amount, range of support (charging infrastructure, special laneways etc) and length of time over which this support will be

3. https://emc-mec.ca/wp-content/uploads/EMC-Sales-Report-2019-Q3_EN_v2.pdf Accessed May 26, 2020 
available. Canadian research has mainly focused on consumer perception towards EVs within urban areas in British Columbia (Krause et al, 2013) and in Quebec (Wielinski et al, 2017) with one study using mystery shoppers experience in Ontario (Matthews et al, 2017). Their outputs reflect the somewhat heterogeneous nature of research trends that suggest poor consumer education levels hinder EV uptake and marketability. 'Range anxiety' or the fear that one's vehicle will run out of electricity without charging stations nearby is a major barrier to adoption of EVs in Canada. But in the case of Quebec, even though cold temperatures limited the likelihood of using an EV (Wielinski et al, 2017) there have been significant increases in their uptake in recent years.

A targeted survey of over 1,700 Canadian EV owners and EV-oriented car buyers found that the Plug in Hybrid EV (PHEV) model is most likely to have mass appeal once a consumer has accepted the possibility of EV ownership (Axsen et al, 2015). Research relevant to adoption of EVs in Ontario has focused on electricity-grid interactions and battery development from a more technical perspective (Hajimiragha et al, 2010; Jarrett and Kim 2011; Musavi et al, 2011; Liu et al, 2013; Ahmadi et al, 2014;). Outside of North America, studies clustered in Scandinavia and Western Europe have found that EV acceptance can increase by simultaneously imposing a direct cost on fuel purchases by ICE vehicles and by providing incentives to reduce the purchase price of EVs (Cordera et al, 2019). Other incentives such as allowing EVs to use the bus lane, avoid paying road tolls and providing multiple rapid charging facilities can also encourage adoption (Browning, 2019). As energy security is of national importance (Rietman and Lieven, 2019) and the transportation sector is a significant contributor of GHG emissions (Kang and Holbrook, 2015), it is important to go beyond price and performance of EVs and infrastructure facilities to understand consumer reluctance to adoption.

\subsection{EV Technology Acceptance Model}

Past research has used cognitive and normative behaviour models to study acceptance of new products and services. Knowledge about how consumers perceive and react to innovation has practical implications that extend beyond contributing to the state of literature, as this information is insightful to leaders in both policy and industry sectors. In the case of an EV, 'accepting' the technology implies both purchasing and utilizing the vehicle. With generally low modal representations worldwide, a framework is necessary to better understand the initial conditions that promote (or hinder) eventual successful diffusion in the market as suggested by Rogers' (1962, 2003) diffusion of innovations theory (DI). Consumers are reluctant to adopt a new technology as they are unsure of its performance and the relatively high price of products generated by a new technology (Rogers, 1962, 2003). EVs are in the early stage of technology (Peters and Dütschke, 2014; Rietman and Lieven, 2019) and we seek to understand consumer decision making regarding purchasing such a vehicle.

The theory of reasoned action (TRA), is often used to understand decision making of users (Ajzen and Fishbein, 1975; Singh et al., 2019). TRA suggests that individuals attitude helps to predict their behaviour for a variety of actions. TRA is a general, broad theory that describes the relationship between behavioural intent, attitude, and subjective norms to predict consumer action (Ajzen and Fishbein, 1975). This conceptual model decodes the relationship between attitude and behaviour based on the principles of compatibility and behavioural intent. However, the theory makes a restrictive assumption that people are always rational and consciously seek and use information at their disposal to analyze the implications of their actions prior to selecting a particular behaviour (Ajzen and Fishbein, 1980). The theory of planned behavior (TPB) which complements TRA addresses the above limitation by adding another construct, perceived behavior control which is an additional determinant of intention and behavior recognizing that if individuals 
believe a particular behavior as productive, they are more likely to engage in that behavior (Ajzen 1985). For e.g. college students' intention to use Information Technology was linked to their desire to work collaboratively and their belief that information technology would help them in this (Cheng et al., 2016). TPB has been successfully applied to study adoption of various technologies: for e.g. predicting adoption of technology-based self-service outlets (Bobbitt and Dabholkar 2001); choice of household technology (Brown and Venkatesh 2005), acceptance of telemedicine (Chau and $\mathrm{Hu}$ 2012) etc. The TRA and TPB were complemented by the technology acceptance model (TAM), to account for the distinct attributes of information systems theory. TAM predicts the likelihood of an individual using a product they have been introduced to by analyzing two external variables: 'perceived usefulness' and 'perceived ease of use' (Davis, 1993) and later expanded to also include 'social norms' to predict the likelihood of adoption (Taylor and Todd, 1995).

To better understand EV adoption, Peters and Dütschke, (2014) applied the DI theory and the preceding theories of users' adoption of an innovation to specifically query consumer intention to purchase and use an EV in a study involving respondents across Germany [Figure 1] but did not account for regional differences and was not representative of the German population. While Peters and Dütschke's (2014) model provides the basis for our choice of inferential variables, a further review of the literature suggests that certain pertinent questions were excluded in their study which should be included to understand EV adoption. In particular we suggest that two factors ignored in their study 1 ) the role of government incentives to make EVs more attractive (Kumar and Kumar, 2020; Rietman and Lieven, 2019) and 2) engagement between parties directly affected by the product - potential users and car dealerships (de Reubens et al 2018; Matthews et al, 2017) need to be considered. Accordingly, their model has been refined [Figure 2] to predict consumer EV purchase decision-making in our study. The novelty of our research is twofold: first we present a more comprehensive model that combines different factors that have hitherto been studied separately to understand their significance when combined with other factors notably 1) knowledge of government incentives as part of the Relative Advantages factor due to their contribution in reducing the price of EVs to be more competitive with ICE vehicles and 2) engagement between potential users and car dealerships as a measure of Observability as mere visibility of EVs measured by potential users visit to dealerships (Peters and Dütschke's, 2014) may not influence potential users but engaging with dealers who they trust and may have a prior relationship with could help them understand the consequences of buying an EV and thereby influence their choice. Second, we study adoption of EVs in a specific geographic context, the GTHA, where almost $20 \%$ of Canada's population lives and generates approximately a fifth of its GDP. The GTHA also provides a unique context as here the provincial government removed incentives to purchase EVs in 2018 and as the survey data was acquired before the government removed incentives, it allows us to gauge whether incentives played a role in influencing consumers to evaluate EVs and thereby inform future public policy.

\section{Methodology}

Our study focuses on "What influences consumer cognizance of EVs and their intent to purchase one as a next vehicle in Ontario?" In addressing this question, we use the GTHA as our geographic location of interest and apply our model on intention and usage of an EV. We designed the online survey to query ICE vehicle owners about their attitudes and perceptions in line with the model's identified drivers of EV adoption. We used an Internet survey device as it enables visual aids, automates user experience and data collection, and expedites data analysis (Zhang, 2000; Berrens et al, 2004; Smyth et al, 2010;). There is a possible limitation that mainly participants who 


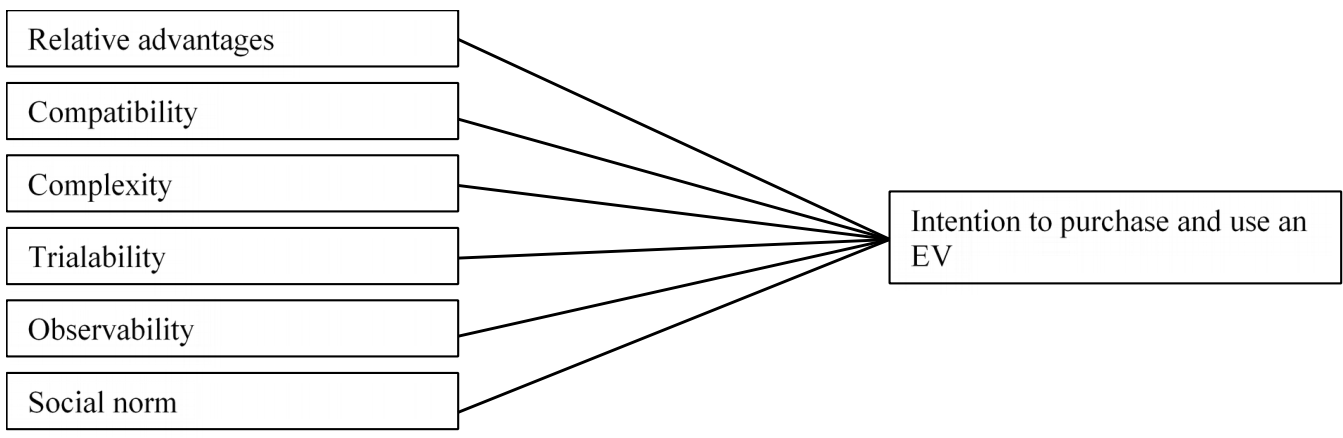

Figure 1. Intention to purchase and use an electric vehicle model (Peters and Dütschke, 2014)

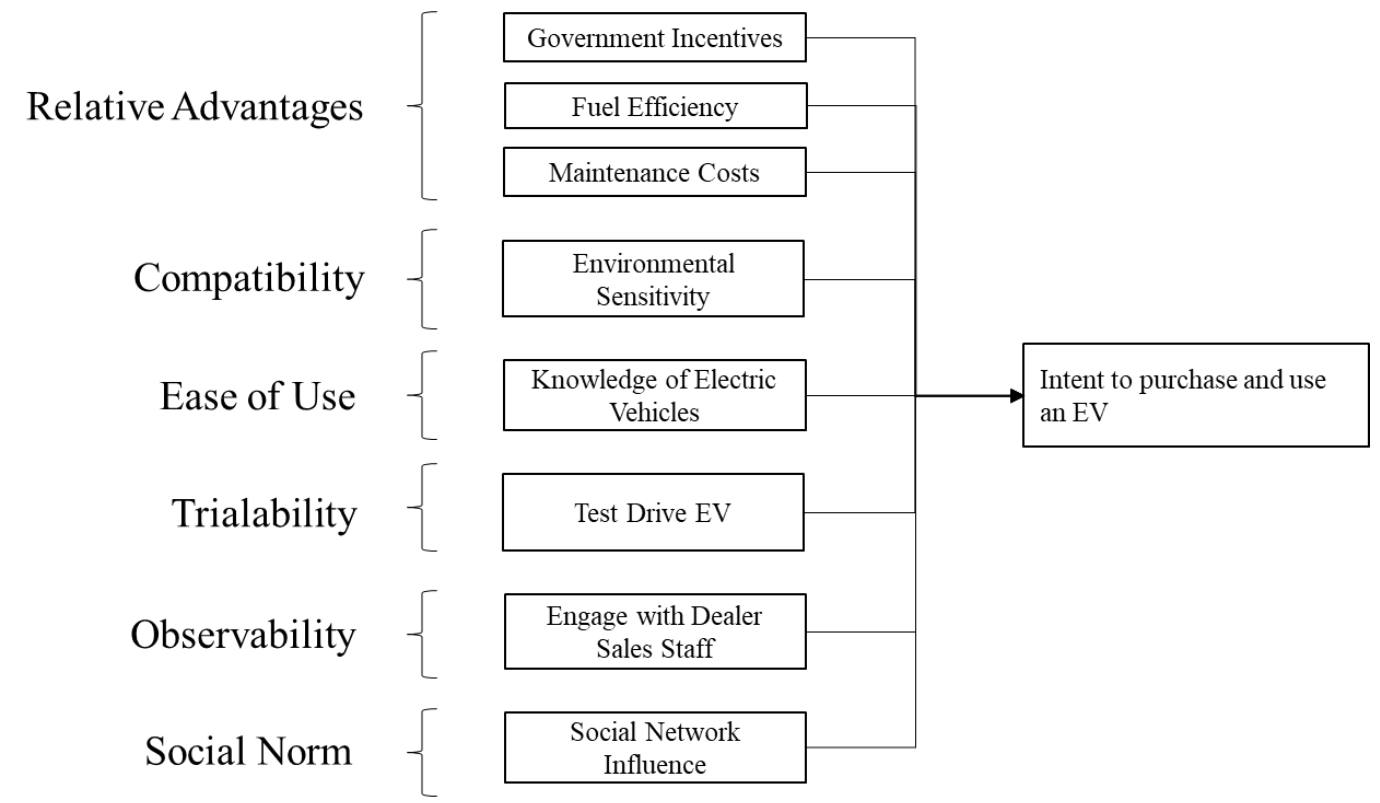

Figure 2. EV adoption model [adapted from Peters and Dütschke (2014)]

are comfortable using the Internet are included and may influence the survey results, but given the economic means necessary to own or lease a vehicle, this factor may have minimal influence (Evans and Mathur, 2005). Surveys conducted over the Internet through a secure platform allow perhaps greater confidentiality in comparison to paper surveys or interview-based surveys (Ahern, 2005; Coutts and Jann, 2011). A professional survey firm was used to acquire 1000 responses to the survey from their database of ICE drivers, eighteen years of age or older, who were resident in the GTHA (of which 3 were subsequently found incomplete and were discarded). In order to limit measurement error and to improve the validity or reliability of the retrieved data the survey was designed around the established constructs identified in the literature review and multiple items were used to measure each construct. Table 1 provides an overview of the questions we developed to measure each inferential variable that we identified in our model. We also asked questions to ensure that only respondents that were of legal driving age, possessed a valid driver's license, owned or leased at least one vehicle, possessed residency in the GTHA, and were willing to complete the survey were included. Consistent with Peters and Dütschke's (2014) study, we also asked specific descriptive questions related to gender, age, number of members in the household, type of house lived in, household income, and education level to better understand potential EV adopters. The online survey was distributed to ICE vehicle owners $(n=1,000)$ within the GTHA. 
All participants were provided with a secure link to complete the survey through the email they provided to undertake the survey. The participants were included from across the municipalities within the GTHA, allowing for fair representation across the region. Once the data was extracted, statistically significant relationships were identified to illustrate which co-variates could influence the model and form predictive measures pertaining to encouraging EV adoption and also influence policy making.

Table 1. Summary of literature support for variable identification and Question development for study

\begin{tabular}{|c|c|c|c|}
\hline $\begin{array}{l}\text { Combined factors } \\
\text { from Peters and } \\
\text { Dütschke (2014) } \\
\text { and this paper }\end{array}$ & Description of factor & $\begin{array}{l}\text { Inferential } \\
\text { variable to be } \\
\text { measured }\end{array}$ & $\begin{array}{l}\text { Question(s) to be asked for } \\
\text { respondents }\end{array}$ \\
\hline $\begin{array}{l}\text { Intent to purchase } \\
\text { and use an EV }\end{array}$ & & $\begin{array}{l}\text { Intent to } \\
\text { purchase and } \\
\text { use an EV }\end{array}$ & $\begin{array}{l}\text { For your next vehicle purchase or lease, } \\
\text { how likely are you to purchase a BEV or } \\
\text { PHEV? }\end{array}$ \\
\hline \multirow[t]{3}{*}{$\begin{array}{l}\text { Relative } \\
\text { advantages }\end{array}$} & $\begin{array}{l}\text { The relative advantages } \\
\text { (and disadvantages) of an } \\
\text { innovation compared to } \\
\text { conventional alternatives } \\
\text { on the market }\end{array}$ & Fuel costs & $\begin{array}{l}\text { What was the fuel economy rating (or } \\
\text { fuel economy equivalency for electric } \\
\text { vehicles) that you wanted your new car to } \\
\text { achieve? }\end{array}$ \\
\hline & & $\begin{array}{l}\text { Maintenance } \\
\text { costs }\end{array}$ & $\begin{array}{l}\text { When selecting a car to purchase or lease, } \\
\text { did you consider the amount of money } \\
\text { you would spend each year in } \\
\text { maintenance and repair costs? }\end{array}$ \\
\hline & & $\begin{array}{l}\text { Knowledge of } \\
\text { government } \\
\text { incentives }\end{array}$ & $\begin{array}{l}\text { To what extent do you know about the } \\
\text { incentive programs available? }\end{array}$ \\
\hline Compatibility & $\begin{array}{l}\text { The compatibility with } \\
\text { the adopter's values, } \\
\text { experiences and needs }\end{array}$ & $\begin{array}{l}\text { Environmental } \\
\text { sensitivity }\end{array}$ & $\begin{array}{l}\text { My choice of personal automobile has an } \\
\text { effect on GHG emissions in the GTHA }\end{array}$ \\
\hline Ease of use & $\begin{array}{l}\text { The complexity, i.e. } \\
\text { difficulty to understand } \\
\text { and use the innovation }\end{array}$ & $\begin{array}{l}\text { Knowledge of } \\
\text { electric vehicles }\end{array}$ & $\begin{array}{l}\text { Do you know enough about "alternative } \\
\text { vehicles" to make an informed choice } \\
\text { about potentially purchasing one in the } \\
\text { future? }\end{array}$ \\
\hline Trialability & $\begin{array}{l}\text { The trialability, i.e. the } \\
\text { possibility to test the } \\
\text { innovation before the } \\
\text { decision to adopt }\end{array}$ & $\begin{array}{l}\text { Test drive } \\
\text { electric vehicle }\end{array}$ & $\begin{array}{l}\text { Prior to purchasing or leasing your new } \\
\text { vehicle did you try test driving an Electric } \\
\text { Vehicle? }\end{array}$ \\
\hline Observability & $\begin{array}{l}\text { The observability or } \\
\text { visibility of an innovation } \\
\text { and its consequences }\end{array}$ & $\begin{array}{l}\text { Engaging with } \\
\text { dealers }\end{array}$ & $\begin{array}{l}\text { When reviewing potential makes and } \\
\text { models, did you ask the dealer questions } \\
\text { to help you understand the vehicle better? }\end{array}$ \\
\hline Social norm & $\begin{array}{l}\text { An individual's } \\
\text { expectation that this } \\
\text { behaviour is expected by } \\
\text { others }\end{array}$ & $\begin{array}{l}\text { Social network } \\
\text { influence }\end{array}$ & $\begin{array}{l}\text { Prior to purchasing your new vehicle, } \\
\text { were you ever introduced to a plug-in } \\
\text { hybrid or battery electric vehicle by } \\
\text { anyone in your friendship, workplace, } \\
\text { and/or extended family network? }\end{array}$ \\
\hline
\end{tabular}




\section{Results and Discussion}

A summary of the socio-demographic information for the survey participants is presented in Table 2. Our sample of 1000 ICE drivers was reasonably representative of the driving population in the GTHA in terms of gender and consistent with published car ownership statistics (Fink, 2013). According to information from StatsCan there were approximately 0.6 cars per person in the Province of Ontario, which would represent approximately 4 million drivers in the GTHA. Our sample of 1000 drivers provides a confidence interval of approximately $+/-4 \%$ at a $99 \%$ level of confidence (Statistics Canada, 2019). Respondents' ages ranged from 18 to over 80 with relatively equal representation between the age groups. Our sample was representative of the GTHA in terms of household type, number of members residing in the household, household income and level of education, although the higher education category was slightly overrepresented but the outcome is not unusual (Statistics Canada, 2016). We feel it is reasonable to generalize to the entire ICE driver population in the GTHA. Distributions of responses to questions that addressed the inferential variables are presented in Table 3. The variables under consideration were measured using ordinal (rank order) and categorical scales. The dependent variable, "respondents' likelihood of purchasing an EV" was measured on a 5-point Likert scale. Significant observations from that table include a skew in the number of respondents who indicated they were unlikely to purchase an EV, which suggests a pre-disposition towards not purchasing an EV. This is not surprising when one considers that EVs are at the early stages of market adoption and face numerous barriers to adoption as discussed earlier. To address this skew and to understand which factors affect adoption among those potential consumers that expressed a definite choice, the data was collapsed as suggested by DiStefano et al. (2020) into either a yes (very likely or likely) or no (very unlikely or unlikely) and non-committal responses were ignored. The distribution of fuel efficiency responses is also consistent with the mindset of Ontario ICE drivers as opposed to those in Europe (Browning, 2019; Williams, 2019). Since gasoline costs in Ontario remain about half the price that Europeans pay, the relative advantage of fuel cost, as a driver for EV adoption is less. Concern for the environment is evaluated by considering whether the respondent believes that their choice of vehicle affects the environment. Respondents were less likely to purchase an EV as their expectations regarding fuel efficiency increased. This is not surprising as EVs cost much more than a conventional ICE vehicle, and respondents may expect greater fuel economy for the higher price associated with an EV especially as respondents are not very worried about the fuel costs of their ICE vehicles (the highest fuel efficiency expectation was $100 \mathrm{~km}$ for 4 litres versus 12 litres for $100 \mathrm{~km}$ in Table 3). Government incentives for EV purchases have a positive impact on likelihood of purchasing an EV making the case for continued support by the government for an EV to encourage their adoption. Many respondents engaged with dealers in the showroom before purchasing a vehicle, implying that there is scope for using this group (dealers) to directly inform potential buyers. Sensitivity to the environment had a positive impact on intent to purchase an EV as was the ability to test drive an EV. The responses also indicate that a significantly large number of Ontario ICE drivers were not introduced to EVs by their social network or had knowledge of alternative EVs to make an informed choice providing further evidence that EV ownership and the understanding of certain relative advantages has not yet reached the mainstream consumer. 
Table 2. Descriptive statistics

\begin{tabular}{|c|c|c|c|c|c|c|c|c|c|c|c|c|c|}
\hline & \multicolumn{13}{|c|}{ Intent to purchase an EV } \\
\hline & Yes & No & Total & & Yes & No & Undecided & Total & & Yes & No & Undecided & Total \\
\hline Gender & & & & Dwelling Type & & & & & Education & & & & \\
\hline Female & 98 & 232 & 330 & House & 130 & 294 & 235 & 659 & $\begin{array}{l}\text { No high school } \\
\text { diploma }\end{array}$ & 1 & 8 & 5 & 14 \\
\hline Male & 102 & 216 & 318 & Condominium & 37 & 111 & 83 & 231 & High school diploma & 15 & 77 & 49 & 141 \\
\hline Age & & & & Rental Apartment & 34 & 41 & 30 & 105 & Trade certificate & 14 & 26 & 24 & 64 \\
\hline $18-29$ & 46 & 84 & 130 & Household Income & & & & & $\begin{array}{c}\text { University } \\
\text { undergraduate }\end{array}$ & 88 & 220 & 164 & 472 \\
\hline $30-39$ & 54 & 61 & 115 & $<\$ 40,000$ & 25 & 44 & 26 & 95 & $\begin{array}{l}\text { Graduate/ } \\
\text { Professional }\end{array}$ & 80 & 102 & 97 & 279 \\
\hline $40-49$ & 39 & 90 & 129 & $\$ 40,000-\$ 60,000$ & 32 & 64 & 51 & 147 & $\begin{array}{l}\text { Members in } \\
\text { household }\end{array}$ & & & & \\
\hline $50-59$ & 33 & 82 & 115 & $\$ 60,001-\$ 80,000$ & 35 & 68 & 66 & 169 & 1 & 27 & 87 & 61 & 175 \\
\hline $60-69$ & 26 & 94 & 120 & $\$ 80,001-\$ 100,000$ & 28 & 58 & 58 & 144 & 2 & 64 & 164 & 124 & 352 \\
\hline $70-79$ & 2 & 35 & 37 & $\$ 100,001-\$ 120,000$ & 23 & 54 & 34 & 111 & 3 & 55 & 87 & 69 & 211 \\
\hline$>79$ & 2 & 2 & 4 & $\$ 120,001-\$ 140,000$ & 7 & 28 & 25 & 60 & 4 & 32 & 76 & 62 & 170 \\
\hline & & & & $\$ 140,001-\$ 160,000$ & 18 & 21 & 21 & 60 & 5 & 18 & 23 & 27 & 68 \\
\hline & & & & $\$ 160,001-\$ 180,000$ & 4 & 16 & 6 & 26 & 6 & 6 & 11 & 7 & 24 \\
\hline & & & & $\$ 180,001-\$ 200,000$ & 7 & 10 & 11 & 28 & $\begin{array}{l}\text { Did you test-drive } \\
\text { while reviewing }\end{array}$ & 722 & 235 & - & 957 \\
\hline & & & & $>\$ 200,000 /$ year & 11 & 20 & 18 & 49 & & & & & \\
\hline
\end{tabular}

** The dependent variable, "respondents' likelihood of purchasing an EV" ranged from 1-5 with 1 being very likely to purchase and 5 being very unlikely to purchase. This data was further reduced to either yes they are likely to purchase and no they are unlikely to purchase.

Table 4. Statistically significant correlations between descriptive and inferential variables

\begin{tabular}{|c|c|c|c|c|c|c|c|}
\hline & Gender & Age & $\begin{array}{c}\text { Household } \\
\text { Members }\end{array}$ & $\begin{array}{l}\text { Home } \\
\text { Type }\end{array}$ & $\begin{array}{l}\text { Household } \\
\text { Income }\end{array}$ & Education & $\begin{array}{l}\text { Purchase } \\
\text { Intent }\end{array}$ \\
\hline Fuel Efficiency & $0.089^{*}$ & $0.095^{*}$ & & $-0.112^{*}$ & $0.082 *$ & & $\begin{array}{l}-0.133^{*} \\
(\mathrm{n}=290)\end{array}$ \\
\hline Maintenance Costs & & & & & & $0.074 *$ & - \\
\hline $\begin{array}{l}\text { Govt. Incentives } \\
\text { Knowledge }\end{array}$ & $0.100^{*}$ & & & $0.057^{*}$ & & $0.132 *$ & $\begin{array}{l}0.268 * \\
n=275\end{array}$ \\
\hline Engaging with Dealer & & $0.193^{*}$ & & & & & $\begin{array}{l}0.199^{*} \\
\mathrm{n}=200\end{array}$ \\
\hline $\begin{array}{l}\text { Social Network } \\
\text { Influence }\end{array}$ & $0.094 *$ & & & & & $0.078^{*}$ & $\begin{array}{l}0.133^{*} \\
\mathrm{n}=199\end{array}$ \\
\hline $\begin{array}{l}\text { Environmental } \\
\text { Sensitivity }\end{array}$ & & & $0.063^{*}$ & & & & $\begin{array}{l}0.297^{*} \\
\mathrm{n}=174\end{array}$ \\
\hline Test Drive EV & $0.074^{*}$ & $-0.075 *$ & & & & & $\begin{array}{l}0.359 * \\
n=174\end{array}$ \\
\hline Knowledge of EVs & $0.262^{*}$ & $0.081^{*}$ & & $-0.087^{*}$ & & $0.126 *$ & $0.166^{*} \mathrm{n}=142$ \\
\hline Purchase Intent & - & $-0.208 *$ & $0.131^{*}$ & & $0.099^{*}$ & $0.138^{*}$ & \\
\hline
\end{tabular}

*. Correlation is significant at the 0.1 level (2-tailed). 
Table 5. Statistically significant correlations $(\mathrm{R})$ between inferential variables

\begin{tabular}{|c|c|c|c|c|c|c|c|c|c|c|c|}
\hline & $\begin{array}{c}\text { Fuel } \\
\text { Efficiency }\end{array}$ & $\begin{array}{l}\text { Maintenanc } \\
\text { Costs }\end{array}$ & $\begin{array}{l}\text { Govt. } \\
\text { Incentives } \\
\text { Knowledge }\end{array}$ & $\begin{array}{l}\text { Engagi } \\
\text { with } \\
\text { Dealer }\end{array}$ & $\begin{array}{l}\text { ngSocial } \\
\text { Network } \\
\text { Influence }\end{array}$ & $\begin{array}{l}\text { Environmen } \\
\text { sensitivity }\end{array}$ & $\begin{array}{l}\text { talest } \\
\text { Drive } \\
\text { EVs }\end{array}$ & $\begin{array}{l}\text { Alternatives } \\
\text { Knowledge }\end{array}$ & $\begin{array}{l}\text { Purchase } \\
\text { Intent }\end{array}$ & Mean & $\begin{array}{l}\text { Std. } \\
\text { Dev }\end{array}$ \\
\hline $\begin{array}{l}\text { Fuel } \\
\text { Efficiency }\end{array}$ & 1 & & & & & & & & $\begin{array}{l}-0.133^{*} \\
(\mathrm{n}=290)\end{array}$ & 3.075 & 1.248 \\
\hline $\begin{array}{l}\text { Maintenance } \\
\text { costs }\end{array}$ & & 1 & & & & & & & - & 0.669 & 0.471 \\
\hline $\begin{array}{l}\text { Govt. } \\
\text { Incentives } \\
\text { knowledge }\end{array}$ & $-0.076^{*}$ & $0.158^{*}$ & 1 & & & & & & $\begin{array}{c}0.268^{*} \\
(n=275)\end{array}$ & 0.575 & 0.495 \\
\hline $\begin{array}{l}\text { Engaging } \\
\text { with } \\
\text { Dealer }\end{array}$ & & & & 1 & & & & & $\begin{array}{c}0.199^{*} \\
(n=200)\end{array}$ & 0.81 & 0.393 \\
\hline $\begin{array}{l}\text { Social } \\
\text { Network } \\
\text { Influence }\end{array}$ & & $0.181^{*}$ & $0.224 *$ & & 1 & & & & $\begin{array}{c}0.133^{*} \\
(n=199)\end{array}$ & 0.271 & 0.445 \\
\hline $\begin{array}{l}\text { Environmenta } \\
\text { Sensitivity }\end{array}$ & & & $-0.109 *$ & $0.099 *$ & & 1 & & & $\begin{array}{c}0.297^{*} \\
(\mathrm{n}=174)\end{array}$ & 0.813 & 0.393 \\
\hline $\begin{array}{l}\text { Test Drive } \\
\text { EV }\end{array}$ & & $0.111^{*}$ & $0.224 *$ & $0.101^{*}$ & $0.251^{*}$ & & 1 & & $\begin{array}{c}0.359 * \\
(n=174)\end{array}$ & 0.201 & 0.402 \\
\hline $\begin{array}{l}\text { Knowledge } \\
\text { of Evs }\end{array}$ & & $0.222 *$ & $0.365^{*}$ & & $0.183^{*}$ & & $0.192^{*}$ & 1 & $\begin{array}{c}0.166^{*} \\
(n=142)\end{array}$ & 0.732 & 0.444 \\
\hline
\end{tabular}

*. Correlation is significant at the 0.1 level (2-tailed)

Table 6. Multinomial logistic regression results between inferential variables

\begin{tabular}{|c|c|c|c|c|c|c|c|c|}
\hline & Model 1 & Model 2 & Model 3 & Model 4 & Model 5 & Model6 & Model 7 & Model 8 \\
\hline Fuel Efficiency & $-0.135^{* *}$ & $-0.134 * *$ & $-0.127^{* *}$ & $-0.238 * *$ & $-0.239 * *$ & $-0.248 * *$ & $-0.257^{* *}$ & $-0.234 * * *$ \\
\hline $\begin{array}{l}\text { Maintenance } \\
\text { Costs }\end{array}$ & & 0.098 & -0.028 & 0.127 & -0.155 & -0.277 & -0.263 & -0.104 \\
\hline $\begin{array}{l}\text { Govt. } \\
\text { Incentives } \\
\text { Knowledge }\end{array}$ & & & $.773 * * *$ & $909 * * *$ & $.886^{* * *}$ & $.986 * * *$ & $0.764^{* * *}$ & $0.634 * * *$ \\
\hline $\begin{array}{l}\text { Engaging with } \\
\text { Dealer }\end{array}$ & & & & $.899 * *$ & $.905 * *$ & $.854^{* *}$ & $.790 * *$ & $0.665^{* * *}$ \\
\hline $\begin{array}{l}\text { Social Network } \\
\text { Influence }\end{array}$ & & & & & $0.375^{*}$ & 0.296 & 0.065 & 0.123 \\
\hline $\begin{array}{l}\text { Environmental } \\
\text { sensitivity }\end{array}$ & & & & & & $1.584^{* *}$ & $1.56^{* * *}$ & $1.567^{* *}$ \\
\hline Test Drive EV & & & & & & & $1.028 * *$ & $1.187 * *$ \\
\hline $\begin{array}{l}\text { Knowledge of } \\
\text { EVs }\end{array}$ & & & & & & & & 0.171 \\
\hline _cons & $0.284^{*}$ & $-0.205^{*}$ & $-.190 * * *$ & $-.569 * * *$ & $-.635 * * *$ & $-1.887^{* *}$ & $-1.775 * * *$ & $-1.871^{* * *}$ \\
\hline $\mathrm{N}$ & 290 & 275 & 275 & 200 & 199 & 174 & 174 & 142 \\
\hline Prob>chi2 & $* *$ & $*$ & $* * *$ & $* * *$ & $* * *$ & $* * *$ & $* * *$ & $* * *$ \\
\hline Pseudo R2 & 0.013 & 0.014 & 0.076 & 0.16 & 0.170 & 0.263 & 0.307 & 0.302 \\
\hline
\end{tabular}

$\mathrm{p}<.1=^{*}, \mathrm{p}<.05=* *, \mathrm{p}<.000=* * *$

We used STATA 14.2 statistical software to identify statistically significant associations 
between the descriptive variables and the inferential variables as shown in Table 4. The correlation coefficients were generally weak, but these results were perhaps not surprising given the mixed results of associating income, age, education, gender and household size with the propensity to own or drive an EV. This is consistent with the mixed findings in previous literature. For example, some research (Egbue and Long, 2012) found no statistical significance related to gender, age, income or level of education and the likelihood to purchase an alternative fuel vehicle while others (Berliner et al, 2019) found evidence to suggest that the likelihood of purchasing an EV increases when respondents are male, younger, have higher income, and are more educated. However, our more statistically significant results were consistent with Berliner et al. (2019) in that higher educated, younger respondents tended to be more willing to purchase an EV and male respondents were likely to be more knowledgeable about EV technology. We also found that older customers would be more inclined to engage with the dealer and that awareness of government incentives would likely exist among educated males.

Table 5 shows the results of correlations between the inferential variables. These variables are representative of the factors that drive adoption of EVs as prescribed in the model. Fuel efficiency, knowledge of government incentives, engaging with dealers, test driving an EV and environmental sensitivity are associated with the respondents' likelihood of purchasing an EV. Trialability (Rezvani et al., 2015; Adnan et al, 2017; Jansson et al, 2017;) is an important contributor to the adoption of EVs and increasing the actual look and running of the cars would further improve attractiveness of these vehicle. Knowledge of government incentives is negatively associated with lower fuel efficiency and this suggests the importance of incentives for cost-conscious drivers, many of whom are likely to drive fuel efficient vehicles. This is further supported by the positive association between the level of knowledge of government incentives and the likelihood that the driver considers maintenance costs as part of their purchase decision, again suggesting that respondents who are more sensitive to cost would seek to know more about how government incentives could reduce their cost of purchasing an EV. There is a relatively weak negative association between knowledge of government incentives and environmental sensitivity and this aligns with the earlier research (Peters and Dutschke 2014) where those with a concern for the environment were not necessarily driven by government incentives to buy an EV. Furthermore, there is a moderate association between the intent to purchase an EV and a concern for the environment, consistent with recent research (Wang et al, 2018). The association between engaging with a dealer (asking questions) and considering a vehicle purchase confirms support for findings (Matthews et al., 2017) that engagement between two parties directly affected by the new technology is important to enable its successful diffusion in the market. Another finding of interest is the negative association between fuel efficiency and the intent to purchase. Although the strength of association is moderately weak, this result suggests that drivers who seek more fuel efficiency are more likely to purchase an EV. However, there are no corresponding correlations with levels of maintenance costs or environmentally sensitivity where one might expect an association with better fuel efficiency (lower fuel cost and less fossil fuel consumed). An explanation may be found in the descriptive statistics where a moderately weak correlation exists between households with more family members and the intent to purchase an EV. An EV is often purchased as a second vehicle for the household to be used when the family vehicle is being used. Second vehicles tend to be smaller and therefore more fuel efficient and therefore this may be the reason for the resulting association between those who considered purchasing an EV and the importance of fuel efficiency when considering the purchase of a new vehicle.

Following these more significant relationships we have employed logit regression to test further the relationships between our dependent variable and our inferential variables (explanatory 
variables). We present the explanatory capabilities of our model in Table 6. The regression results for ICE vehicle drivers identify fuel efficiency and knowledge of government incentives (relative advantage drivers), environmental sensitivity (a compatibility driver), engaging with dealers (observability) and test drive of an EV (trialability) as statistically significant contributors to modelling the intent to purchase an EV (Model 8 is the full model in Table 6). We aggregate the explanatory variables in a series of regression models (Table 6) to identify the best explanatory model (Model 7) for the intent to purchase an EV (best pseudo R2 $=0.307$ ). The aggregate model remains statistically significant throughout with fuel efficiency, knowledge of government incentives, dealer engagement, trialability and environmental sensitivity having significant influence. Figure 3 provides a visual representation of our results. As test driving an EV has an impact on whether respondents would consider purchasing an EV, more effort should be made at the dealerships to engage with prospective buyers and convince them to test drive an EV. As indicated in the literature review, research on diffusion of innovations suggests various factors that influence customers' choices. However, an important factor that has been acknowledged as important in influencing a potential buyer's decision (de Reubens et al 2018; Matthews et al, 2017), but ignored by Peters and Dutschke (2014), is that the customer's engagement with EV dealerships can influence their decisions. Factors at the point of sale could promote (or impede) respondents' decision to buy an EV. Rather than viewing these factors at the point of sale in isolation, it is important to include it along with the other factors detailed in the innovation adoption literature (Rogers, 1962, 2003). Isolating one factor ignores the impact of the other factors. All sales people are not equally knowledgeable about EV attributes and services as it is a new technology. Attitude of dealers influenced mystery shoppers' inclination to purchase an EV (Matthews et al, 2017). Even after accounting for all the others six factors identified in innovation adoption research, we find that those ICE owners that engaged with dealers indicated that they were more likely to purchase an EV as their next vehicle. Rather than restricting observability (one of the six factors highlighted by past research) to whether or not prospective customers visited dealerships, considering instead whether or not they engaged with dealers would provide a more accurate assessment of what influenced their decision. In a qualitative study involving a sample size of 17 organizations, Valdez et al, (2019) explored the possibility of using EVs in Milton Keynes, UK, and found that acceptance of EVs was influenced by the collective sensemaking of the EV technology among users. An introduction of an innovative technology starts a process of "information-seeking, meaning ascription and action" (Valdez et al, 2019:88) that can encourage adoption or conversely, result in potential users deciding that there is inadequate information and hence no action ought to be taken (Weick, 1995).

\section{Conclusions}

In studying a technology in its early stage of adoption, EVs are peculiar to most consumer technology in that the decision by the market/customers to buy an EV has been influenced through attempts by the government to encourage adoption, due principally to the potential of EVs to reduce GHG emissions. Educating prospective customers about incentive schemes can be important in influencing the likelihood of adoption. However, rather than letting the market take its own course and wait for the prices to decrease with technological improvements and scale, governments have sought to expedite the adoption of this technology by focusing on affordability and expansion of EV infrastructure, the concept of technology push policies versus technology pull policies (Walsh, 2012). There appears to be less emphasis on promoting other adoption factors. To understand what some of those other drivers might be, our research examined what 


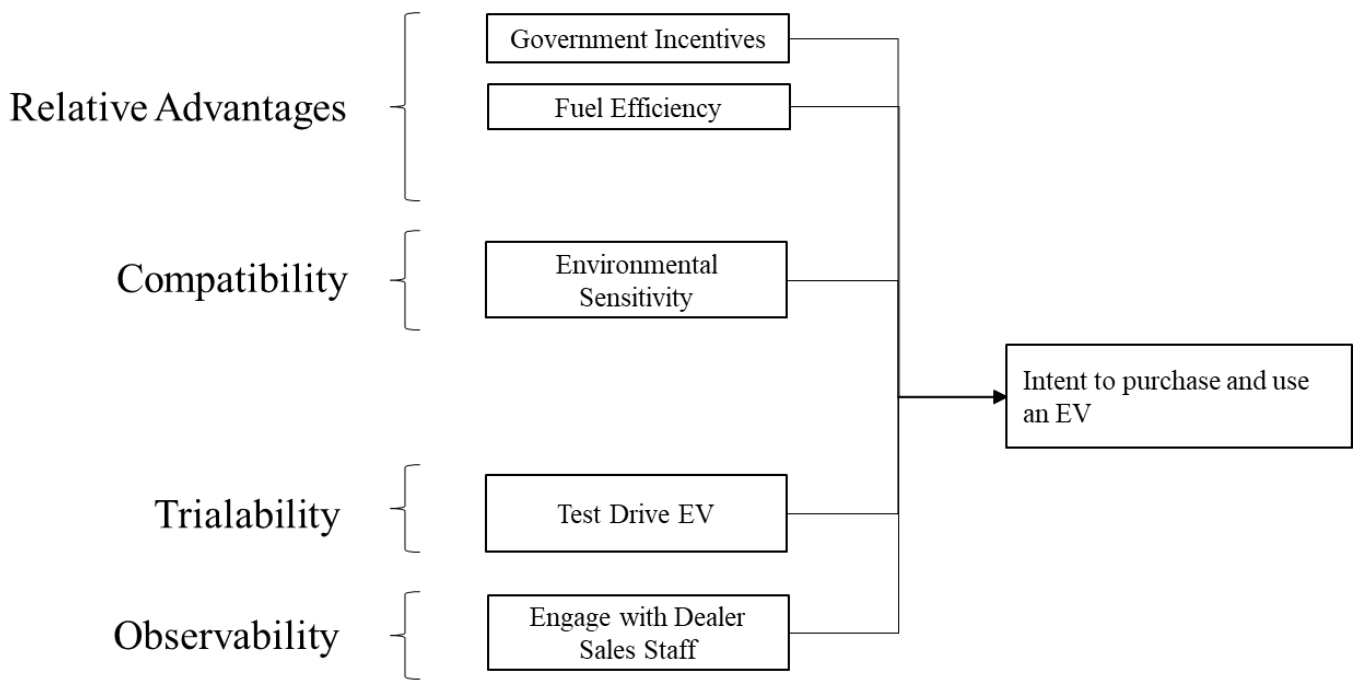

Figure 3. Revised model for adoption of EVs in Ontario, Canada

motivates or demotivates consumers when considering the purchase of an EV. We studied ICE vehicle owners to understand how they differed in their motivations regarding the likelihood of a future EV purchase. The ICE owner is limited in their exposure to the technology so their motivation to consider the purchase of an EV can be stimulated initially through introductory engagement that informs experientially with the assistance of a knowledge broker (the EV Dealer). This is consistent with the view that customer awareness and attitude are shaped by experts' (in this case dealerships) perceptions and anticipation of the market (Barnett et al., 2012; Ballo, 2015;) and user interactions with the innovation can serve as key decision-making points in the evolution of a technology. The assumptions that are considered as important by potential EV buyers play a significant role in how these vehicles are marketed to consumers (Brown, 2001) and instead of only considering consumers as rational, cost focused and environmentally conscious, thereby limiting potential patterns of use, it is useful to imagine a variety of futures (Bergman, et al, 2017). By taking a simplistic functional view that EV adoption is stymied mainly by high initial costs and range anxiety and addressing the same by providing some financial incentives and increased charging infrastructure may not be motivating enough for potential ICE consumers. It stands to reason that consumers would be buying these cars and using them for some time and therefore would be concerned about a variety of aspects related to their purchase.

Consumers seek the opinion of those they trust to be experts in this area, and to that degree EV dealerships and the test drive process can contribute to that trust. Increasing engagement could considerably alleviate concerns and start conversations about the customer's expectations of EV vehicles and the causes for their hesitance in purchasing one. Certainly, policies that improve affordability and availability of charging infrastructure can encourage adoption, but it may be that only those who have taken the leap to purchase EVs find that beneficial. Therefore, those policies appear more important for maintaining adoption. For the greater ICE market segment, policies need to encourage EV producers to establish programs within their dealerships that engage consumers and provide the necessary information to allow for an informed decision about purchasing an EV. Furthermore, dealerships can alleviate any issues related to observability and trialability, such as any consumer mistrust of dealer motives, by working with other infomediaries to jointly educate the consumer. This non-traditional approach is important in stimulating observability and trialability as key drivers for EV adoption. An example of such an arrangement exists with the non-profit Plug 'n Drive Electric Vehicle Discovery Centre in Toronto, Canada which is sponsored 
by auto manufacturers, electric utilities, EV technology companies and other non-profit agencies to promote EV sales. Their site focuses on trialability by providing consumers with access to all makes of EVs for test driving and knowledgeable staff without having to face sales pressure from any particular auto dealership. With a retail-type location it contributes as well to the observability of EVs by consumers.

For the Province of Ontario, encouraging greater dealer involvement may require introducing regulations to promote certain levels of EV sales by some future date. Given future emission regulations in China, Europe and California, United States, vehicle producers are planning to offer consumers greater accessibility and engagement to EVs and, in doing so, hopefully increasing the adoption of EV technology. Dealers would like to remain in business and therefore strive to remain competitive by being part of this new technology. Dealers that provide real time information about consumer preferences, queries and concerns need to be acknowledged and compensated accordingly. Helping them to increase EV sales by providing training, education and creative financing schemes to attract customers would gain their support. As EVs require less servicing compared to ICE vehicles, dealers concern about reduced servicing revenues must be alleviated. Working with battery-based vehicles is different from combustion engine vehicles and requires different skills and knowledge. Manufacturers should invest in developing a multi skilled talent pool (engineers that have knowledge in chemical, electrical and mechanical engineering) who would help in making better and less expensive EVs.

Certainly, car manufacturers must consider the cost implications associated with promoting EVs but such consideration must compare these costs with the longer-term risk that they find themselves as laggards in the market as competitive EV options for consumers increase. EV sales have experienced worldwide growth in the last five years and are expected to be a third of total sales by 2025 . The Canadian automotive sector is a major provider of jobs and economic activity and vehicle manufacturers need to be competitive or risk rapid decline. Canada is the 12th largest vehicle producer in the world but EV production is only $0.4 \%$ of its total vehicle production compared to the global average of $2.3 \%$. As EVs are generally sold in the region where they are manufactured, sales of Canadian EVs domestically can significantly increase with a broad range of incentives, infrastructure and consumer awareness policies to increase demand. Joint alliances between utility companies, vehicle manufacturers and dealers would also help in providing customized electricity charging tariffs based on individual customers needs at the time of EV purchase itself and can make EVs more attractive.

There is often a gap between an individual's beliefs and their actions and while people care about the environment their actions do not match those beliefs (Lane and Potter, 2007). Motivating them by providing different incentives can help. We found that people's knowledge of government incentives had a positive impact on adoption decisions. Creating and properly implementing government policies can influence EV adoption decisions. For example, fast recharge networks that are widely available, can be easily accessed (located effortlessly and consumers can pay conveniently), well maintained, etc. can also have a significant impact on adoption (Yu et al., 2016; Broadbent et al, 2018) as seen in Norway, California in the United States and The Netherlands. Questions remain however as to whether the level of incentives exists to allow for public recognition of the features and benefits of EVs in order to significantly stimulate demand and if not, what further investment would be required to do so. As our paper suggests, it may not be the EV technology that is the issue but rather the need to improve communication and education of the technology through encouraging observability, trialability and dealer engagement.

We recognize certain limitations regarding this research, such as the geographical context and its impact on generalizability and our measure of intent instead of actual purchase. As with any 
research that involves a survey of this type there is a risk of non-response bias and common-method variance in the dataset however the survey was designed to mitigate that bias should it exist. Our research contributes to existing knowledge by extending upon the work of Peters and Dutschke, 2014 and Matthews et al, 2017 by including the role of dealer engagement in investigating the adoption behaviour of ICE drivers. Building the EV market depends upon involvement of those who are directly connected with consumers and are the point of contact for them. Those who have knowledge of both the incumbent technology and the new technology, an area that has not received sufficient attention in research on EV adoption, deserves further attention. Future cognitive and normative behavioural research related to EV adoption could be furthered through qualitative methods, such as interviews, workshops or focus groups with EV users, ICE users and car dealers, that could result in deeper insight into understanding what factors influence adoption of EVs.

\section{Acknowledgement}

We are grateful to Plug N Drive for helping us with our data collection.

\section{References}

Adnan, N., Nordin, S. M., Rahman, I., Vasant, P.M. \& Noor, A. (2017). A comprehensive review on theoretical framework-based electric vehicle consumer adoption research. International Journal of Energy Research, 41, 317-335. https://doi.org/10.1002/er.3640

Ahern, N. R. (2005). Using the Internet to conduct research. Nurse Researcher, 13, 55-70. DOI:10.7748/nr2005.10.13.2.55.c5968

Ahmadi, L., Yip, A., Fowler, M., Young, S.B., \& Fraser, R.A. (2014). Environmental feasibility of re-use of electric vehicle batteries. Sustainable Energy Technologies and Assessments, 6, 64-74. https://doi.org/10.1016/j.seta.2014.01.006

Ajzen, I.,\& Fishbein, M. (1975). Belief, attitude, intention and behavior: An introduction to theory and research. (Reading, MA: Addison-Wesley).

Ajzen, I., \& Fishbein, M. (1980). A theory of reasoned action. Understanding attitudes and predicting social behaviour. Englewood Cliffs, NJ: Prentice-Hall.

Ajzen, I. (1985). From intentions to actions: A theory of planned behavior. Action control. Springer Berlin Heidelberg.

Axsen, J., \& Kurani, K. S. (2012). Interpersonal influence within car buyers' social networks: applying five perspectives to plug-in hybrid vehicle drivers. Environment and Planning A: Economy and Space, 44, 1047-1065. https://doi.org/10.1068/a43221x

Axsen, J., Goldberg, S., \& Bailey, H.J. (2015). Electrifying Vehicles: Insights From the Canadian Plug-in Electric Vehicle Study. Sustainable Transportation Research Team, Simon Fraser University, Vancouver, British Columbia.

Ballo, I.F. (2015). Imagining energy futures: sociotechnical imaginaries of the future smart grid in Norway. Energy Research and Social Science. 9, 9-20.

Barnett, J., Burningham, K., Walker, G., \& Cass, N. (2012). Imagined publics and engagement around renewable energy technologies in the UK. Public Understanding Sci.21, 36-50.

Bergman, N., Schwanen, T., \& Sovacool, B.K. (2017). Imagined people, behaviour and fu- 
ture mobility: insights from visions of electric vehicles and car clubs in the United Kingdom. Transportation Policy 59, 165-173.

Berliner, R. M., Hardman, S., \& Tal, G. (2019). Uncovering early adopter's perceptions and purchase intentions of automated vehicles: Insights from early adopters of electric vehicles in California. Transport Research Part F: Traffic Psychology and Behaviour, 60, 712-722. https://doi.org/10.1016/j.trf.2018.11.010

Berrens, R. P., Bohara, A. K., Jenkins-Smith, H. C., Silva, C.L., \& Weimer, D.L. (2004). Information and effort in contingent valuation surveys: application to global climate change using national internet samples. Journal of Environmental Economics and Management,47, 331-363. https://doi.org/10.1016/S0095-0696(03)00094-9

Bobbitt, L.M \& Dabholkar, P.A. (2001). Integrating attitudinal theories to understand and predict use of technology-based self-service. The Internet as an illustration. International Journal of Service Industry Management, 12, 423 -450 http://dx.doi.org/10.1108/EUM0000000006092

Broadbent, G.H., Drozdzewski, G, \& Metternicht, D. (2018). An Analysis of best practice and pitfalls for policy making from experiences of Europe and the US. Geography Compass 12: https://doi.org/10.1111/gec3.12358

Brown, M.B., (2001). The civic shaping of technology: California's electric vehicle program. Science Technology Human Values, 26, 56-81.

Brown, S. A. \& Venkatesh, V. (2005). A Model of Adoption of Technology in the Household: A Baseline Model Test and Extension Incorporating Household Life Cycle. MIS Quarterly, 29: 399-426. DOI: $10.2307 / 25148690$

Browning, S. (2019). I drive in the bus lane. BBC.

Retrieved from https://www.bbc.com/news/business-48400271

Chau, P. Y. K., \& Hu, P. J. (2002). Examining a model of information technology acceptance by individual professionals: An exploratory study. Journal of Management Information Systems, 18, 191-229. https://doi.org/10.1080/ 07421222.2002.11045699.

Coutts, E., \& Jann, B. (2011). Sensitive questions in online surveys: Experimental results for the randomized response technique (RRT) and the unmatched count technique (UCT). Sociological Methods \& Research, 40, 169-193. https://doi.org/10.1177/0049124110390768

Cordera, R., Luigi dell'Olio, Angel Ibeas, \& Ortuzar, J. D. (2019). Demand for environmentally friendly vehicles: A review and new evidence. International Journal of Sustainable Transportation. 13: 210-223. https://doi.org/10.1080/15568318.2018.1459969

Davis, F.D. (1993). User acceptance of information technology: system characteristics, user perceptions and behavioral impacts. International Journal of Man-Machine Studies, 38: 475-487. doi: $10.1006 /$ imms.1993.1022

De Reubens, G.Z., Noel, L. \& Sovacool, B.K. (2018). Dismissive and deceptive car dealerships create barriers to electric vehicle adoption at the point of sale. Nature Energy 3, 501-507. https://doi.org/10.1038/s41560-018-0152-X

DiStefano, C., Shi, D., \& Morgan, G. B. (2020). Collapsing Categories is Often More Advantageous than Modeling Sparse Data: Investigations in the CFA Framework. Structural Equation Modeling: A Multidisciplinary Journal, 1-13.

Egbue, O., \& Long, S. (2012). Barriers to widespread adoption of electric vehicles: An analysis of 
consumer attitudes and perceptions. Energy policy, 48, 717-729. doi: 10.1016/j.enpol.2012.06.009

Evans, J. R., \& Mathur, A.(2005). The value of online surveys. Internet Research, 15, 195- 219. DOI:10.1108/10662240510590360

Fink, G. (2013). 2 Charts That Prove Men And Women Have Nothing In Common When It Comes To Cars. Huffington Post, Accessed on May 30, 2020. http://www. huffingtonpost.ca/entry/carsmen-drive-women_n_4520727

Hajimiragha, A., Canizares, C. A., Fowler, M. W., \& Elkamel, A. (2010). Optimal transition to plug-in hybrid electric vehicles in Ontario, Canada, considering the electricity-grid limitations. IEEE Transactions on Industrial Electronics, 57, 690-701. DOI: 10.1109/TIE.2009.2025711

Jansson, J., Nordlund, A., \& Westin, K. (2017). Examining the drivers of sustainable consumption: The influence of norms and opinion leadership on electric vehicle adoption in Sweden. Journal of Cleaner Production. 154: 176-187. https://doi.org/10.1016/j.jclepro.2017.03.186

Jarrett, A., \& Kim, I. Y. (2011). Design optimization of electric vehicle battery cooling plates for thermal performance. Journal of Power Sources, 196, 10359-10368.

doi: $10.1016 /$ j.jpowsour.2011.06.090

Kang, D. \& Holbrook J. (2015). Use of NH3 fuel to achieve deep greenhouse gas reductions from US transportation. Energy Reports.1:164-168. https://doi.org/10.1016/j.egyr.2015.08.001

Krause, R. M., Carley, S., Lane, B. W., \& Graham, J.D. (2013). Perception and reality: Public knowledge of plug-in electric vehicles in 21 US cities. Energy Policy, 63, 433-444. doi:10.1016/j.enpol.2013.09.018

Krause R, Lane B, Carley S, \& Graham J. D. (2016). Assessing demand by urban consumers for plugin electric vehicles under future cost and technological scenarios. International Journal of Sustainable Transportation, 10, 742-751. https://dx.doi.org/10.1080/15568318.2016.1148213

Klippenstein, M. 2019. Green Car Reports. Retrieved from www.CanadaEVsales.com and www.tinyurl.com/CanadaEVsales last accessed on Feb 7, 2021

Koropeski, A., Loane, G., \& Gough, J. (1998). Toronto- making room for all modes. Institute of Transportation Engineers. 68, 42-46. Retrieved from http://ezproxy.lib.ryerson.ca/login?url=https://searchproquest-com.ezproxy.lib.ryerson.ca/docview/224866226?accountid=13631

Kumar, R.R. \& Kumar, A. (2020). Adoption of electric vehicles: A literature review and prospects for sustainability. Journal of Cleaner Production. 253:119911.

https://doi.org/10.1016/j.jclepro.2019.119911

Lane, B. \& Potter, S. (2007). The adoption of cleaner vehicles in the UK: Exploring the consumer attitude-action gap. Journal of Cleaner production. 15:1085-1092. https://doi.org/10.1016/ j.jclepro.2006.05.026

Levinson, D. M., Gillen, D., \& Kanafani, A. (1998). The social costs of intercity transportation: a review and comparison of air and highway. Transport Reviews, 18, 215-240. doi: $10.1080 / 01441649808717014$

Liu, Z., Wen, F., \& Ledwich, G. (2013). Optimal planning of electric-vehicle charging stations in distribution systems. IEEE Transactions on Power Delivery, 28, 102-110.

DOI: $10.1109 / T P W R D .2012 .2223489$

Liu, Y.,\& Cirillo, C. (2018). Modeling green vehicle adoption: An integrated approach for policy 
evaluation. International Journal of Sustainable Transport, 12, 473-483.

doi:10.1080/15568318.2017.1393584

Matthews, L., Lynes, J., Riemer, M., Matto, T.D., \& Cloet N. (2017). Do we have a car for you? Encouraging the uptake of electric vehicles at point of sale. Energy Policy, 100, 79-88. http://dx.doi.org/10.1016/j.enpol.2016.10.001

Melton, N., Axsen, J.,\& Goldberg, S. (2017). Evaluating plug-in electric vehicle policies in the context of long-term greenhouse gas reduction goals: Comparing 10 Canadian provinces using the "PEV policy report card". Energy Policy, 107, 381-393. doi: 10.1016/j.enpol.2017.04.052

McKitrick, R. (2006). The politics of pollution: party regimes and air quality in Canada. Canadian Journal of Economics, 39, 604-620. https://doi-10.1111/j.0008-4085.2006.00362.x

Musavi, F., Eberle, W., \& Dunford, W. G. (2011). A high-performance single-phase bridgeless interleaved PFC converter for plug-in hybrid electric vehicle battery chargers. IEEE Transactions on Industry Applications, 47, 1833-1843. DOI: 10.1109/TIA.2011.2156753

Nagorsky, B., Sabag, K., Emerson, D., \& Hewitt, S.(2016). Moving Beyond Evaluation to Transit Project Prioritization: Lessons from the Toronto, Ontario, Canada, Context. Transport Research Record: Journal of the Transport Res Board. 2568, 64-71. https://doi.org/10.3141/2568-10

Peters, A., \& Dütschke, E. (2014). How do Consumers Perceive Electric Vehicles? A Comparison of German Consumer Groups. Journal of Environmental Policy and Planning 16, 359-377. http://dx.doi.org/10.1080/1523908X.2013.879037

Rezvani, Z., Jansson, J., \& Bodin, J. (2015). Advances in consumer electric vehicle adoption research: A review and research agenda. Transport Research Part D: Transport and Environment, 34, 122-136. https://doi.org/10.1016/j.trd.2014.10.010

Rogers. E. 1962. Diffusion of innovations (1st ed). New York. Free Press

Rogers, E. 2003. Diffusion of Innovations. (5th ed). New York. Free Press

Rietman, N. \& Lieven, T. (2019). How policy measures succeeded to promote electric mobilityworldwide review and outlook. Journal of Cleaner Production. 206: 66-75.

https://doi.org/10.1016/j.jclepro.2018.09.121

Singh, R., Walsh, P., \& Mazza, C. (2019). Sustainable Housing: Understanding the Barriers to Adopting Net Zero Energy Homes in Ontario, Canada. Sustainability, 11(22), 6236. https://doi.org/10.3390/su11226236

Smyth, J.D., Dillman, D.A., Christian, L.M., \& O'Neill A.C. (2010). Using the Internet to survey small towns and communities: Limitations and possibilities in the early 21st century. American Behavioral Scientist. 53, 1423-1448. DOI:10.1177/0002764210361695

Statistics Canada. New motor vehicle sales. (2019) Retrieved from Table 20-10-0001-01 New motor vehicle sales

Statistics Canada. Motor vehicle registrations, by province and territory. (2016) Retrieved from http://www.statcan.gc.ca/tables-tableaux/sum-som/l01/cst01/trade14a-eng.htm

And http://www12.statcan.gc.ca/census-recensement/2016

Taylor, S., \& Todd, P.A.(1995). Understanding Information Technology Usage: A test of competing models. Information Systems Research, 6, 144-176. https://doi.org/10.1287/isre.6.2.144 
Valdez, A.M., Potter, S., \& Cook, M. (2019). The imagined electric vehicle user: Insights from pioneering and prospective buyers in Milton Keynes, United Kingdom. Transportation Research Part D Transport Environment, 71, 85-95. DOI:10.1016/j.trd.2019.01.010

Walsh, P. R. (2012). Innovation Nirvana or Innovation Wasteland? Identifying commercialization strategies for small and medium renewable energy enterprises. Technovation, 32(1), 32-42. https://doi.org/10.1016/j.technovation.2011.09.002

Wang, N., Tang, L.,\& Pan, H. (2018). Analysis of public acceptance of electric vehicles: An empirical study in Shanghai. Technological Forecasting and Social Change, 126, 284-291. https://doi.org/10.1016/j.techfore.2017.09.011

Webb, K., Cruz, R., \& Walsh, P. R. (2017). A comparative review of the role of markets and institutions in sustaining innovation in cleantech: a critical mass approach. International Journal of Innovation and Sustainable Development, 11(2-3), 149-169. https://doi.org/10.1504/IJISD.2017.083307

Weick, K., (1995). Sensemaking in Organizations, vol. 3 Sage, London.

Williams, D. (2019). For the first time ever, electric cars outsold gas and diesel vehicles in Norway. CNN. Retrieved from https://www.cnn.com/2019/04/04/world/norway-zero-emission-vehiclestrnd/index.html on October 29, 2019

Wielinski, G., Trépanier, M., \& Morency, C. (2017). Electric and hybrid car use in a free-floating carsharing system. International Journal of Sustainable Transport.11: 161-169.

https://doi.org/10.1080/15568318.2016.1220653

Yu, Z., Li, S. \& Tong, L. (2016). Market dynamics and indirect network effects in electric vehicle diffusion. Transportation Research Part D. Transport \& Environment, 47:336-356. Doi.org/10.016/j.trd.2016.06.010

Zhang, Y. (2000). Using the Internet for survey research: A case study. Journal of American Society for Information Science. 51, 57-68. https://doi.org/10.1002/(SICI)1097-4571(2000)51:1<57::AIDASI9>3.0.CO;2-W 


\section{Biographies}

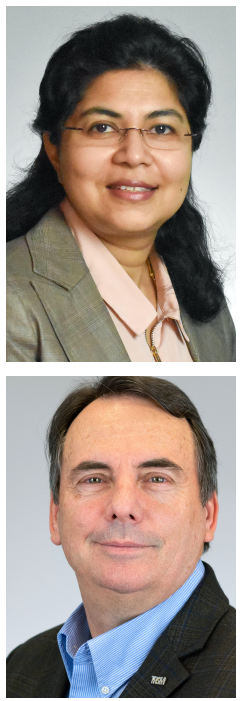

Ranjita M. Singh. Ranjita Singh is an Assistant Professor in the Entrepreneurship \& Strategy department of the Ted Rogers School of Management. Her research involves studying corporate governance, new industries and impact of business incubators. She has published research on net zero housing and corporate governance of Canadian Corporations

CRediT Statement: Formal Analysis, Methodology and Writing

Philip R. Walsh. Philip R. Walsh earned his B.Sc. (Hons) in Geological Sciences from Queen's University at Kingston in 1981, his M.B.A. from the Ivey School of Business, Western University in 1995, and his Ph.D. in Strategic Management from the University of Bradford. He has over 30 years of experience working as a geoscientist and strategic planning consultant. In 1998, he began his PhD studies and in 2003 joined the University of Surrey as a Lecturer in Corporate Strategy. He is currently a Professor in Entrepreneurship and Strategy at the Ted Rogers School of Management, Ryerson University, Toronto, Canada, and a Visiting Research Fellow at the Center for Responsible Management at the University of Winchester, U.K. He has co-authored textbooks on Strategy and Sustainability and has published extensively in those areas. His professional memberships include the Society of Petroleum Engineers, the International Association of Energy Economics, and the Petroleum Exploration Society of Great Britain. Dr. Walsh is also a registered professional geoscientist.

CRediT Statement: Supervision, Investigation and Writing Review

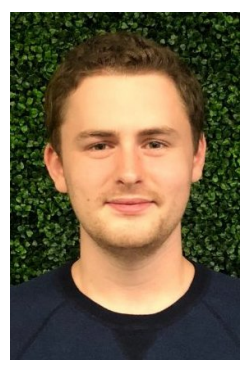

Joshua I. Goodfield. Joshua Goodfield holds a Master of Applied Science and a Bachelor of Arts specializing in innovation management, clean tech, and environmental sciences. He is currently the Partnerships Manager at $\mathrm{C} 100$, a nonprofit organization building the preeminent community of Canadians in technology.

CRediT Statement: Data Curation, Conceptualization and Investigation 